\title{
Chicory seed production: research and practice
}

\author{
M.D. HARE', J.S. ROWARTH ${ }^{2}$, W.J. ARCHIE ${ }^{2}$, M.P. ROLSTON ${ }^{1}$ and B.R. GUY' \\ 'DSIR G rasslands, Private Bag, Palmerston North \\ ${ }^{2}$ DSIR G rasslands, Private Bag, Christchurch \\ 'Challenge Seed, Kimihia Research Centre, P.0. Box 939, Christchurch
}

\begin{abstract}
'Grasslands Puna' chicory (Cichorium intybus L.) has been harvested for seed in New Zealand since 1984. Seed yields have ranged from 0 to over $700 \mathrm{~kg} / \mathrm{ha}$ with an average yield of around $200 \mathrm{~kg} / \mathrm{ha}$. Data from Manawatu and Canterbury trials were combined with information gained from monitoring 25 Puna seed crops in Canterbury. Results from work on establishment, time of closing, seed development, response to nitrogen, herbicide tolerance and methods of harvesting are reported, and differences between Manawatu and Canterbury in terms of management of Puna seed crops are highlighted.
\end{abstract}

K eywords chicory, seed production

\section{Introduction}

'Grasslands Puna' chicory (Cichorium intybus L.) is a perennial, tap-rooted herb gro $\overline{\mathrm{w}} \overline{\mathrm{n}}$ in New Zealand for forage either alone or as part of a herbal ley. Puna has been harvested for seed in New Zealand since 1984. During this time seed yields have ranged from $0 \mathrm{~kg} / \mathrm{ha}$ (when heavy rain rotted the cut sward) to over $700 \mathrm{~kg} / \mathrm{ha}$, and problems of seed quality have arisen (weed seed contamination and low germination).

Results from management trials have been combined with information gained from monitoring 25 Puna seed crops in Canterbury during the 1989/90 growing season to derive the following recommendations.

\section{Establishment}

Time of sowing

Puna chicory can be sown in the spring or early autumn, before the end of March. Because chicory must undergo a period of vernalisation to produce seed heads (George 1985), spring-sown crops will not produce seed until the second summer, 15-18 months after sowing. Spring (October) and autumn (March) sowings have produced 520 and $530 \mathrm{~kg} / \mathrm{ha}$ of seed respectively in the Manawatu (Hare \& Rolston, unpubl. data). In Canterbury, where soil temperatures are lower than in Manawatu, springsummer sowings are recommended rather than autumn sowings. The longer period of springsummer establishment allows for weed control by grazing and means that the plants are sufficiently large by winter for further weed control with herbicides if necessary. Crops sown after midFebruary in Canterbury have only a small tap-root by winter and are more prone to suffering from weed competition, frost or drought than larger plants. Crops sown after March may not become sufficiently established before winter to give a seed crop the following season.

Seeding rate and row spacing

There was no significant difference in seed yield between row spacings of 15,30 and $60 \mathrm{~cm}$ and seeding rates of 2,4 and $8 \mathrm{~kg} / \mathrm{ha}$ in a trial in the Manawatu (Hare \& Rolston, unpubl. data). The highest yields, however, came from spacings and rates similar to those used in India (i.e. $30 \mathrm{~cm}$ rows and 3-5 kg/ha seed, Ayra \& Säini 1984). Although there may-be some-advantage to seed yield in the 30 $\mathrm{cm}$ spacings, the wider spacings allow more bare ground for ingress of weeds and evaporation of moisture. Observation of 25 Puna crops in Canterbury revealed that Puna in $15 \mathrm{~cm}$ rows did not suffer from weeds or drought to the same extent as those crops in wider row spacings.

\section{Weed control}

\section{Establishing crops}

Soil-incorporated herbicides, trifluralin (Treflan, Triflur 40) or EPTC (Eradicane Super), applied before sowing should be used where thistles and broadleaf weeds are particularly troublesome. Chlorpropham (Chloro-IPC) and propyzamide (Kerb Flo) can be applied post-sowing but before emergence to control grass weeds.

In the early establishment period (2-3 months after sowing), bentazone (Basagran) $(1.4 \mathrm{~kg}$ ai $/ \mathrm{ha})$ and metribuzin (Sencor) $(0.5 \mathrm{~kg}$ ai/ha) will control a wide range of broadleaf weeds. The chicory plants must have 5-6 leaves before these herbicides can be applied. Grass weeds can be controlled at any time during chicory's growth with carbetamide (Carbetamex 70) (3.5-4 kg ai/ha), haloxvfop 
(Gallant) (0.25 kg ai/ha), propyzamide (Kerb Flo) (1 $\mathrm{kg}$ ai/ha) and fluzifop-P-butyl (Fusilade) $(0.25 \mathrm{~kg}$ ai/ha).

$M$ ature crops

Atrazine $(0.5-1.0 \mathrm{~kg}$ ai/ha) and paraquat (Gramoxone) (0.4 kg ai/ha) will control a wide range of grasses and broadleaf weeds when applied in midwinter, even for autumn-sown crops, 3-4 months after establishment. Asulam (Asulox) (1.6 kg ai/ha) controls docks (R umex spp.) when applied in early spring, but can check the growth of Puna and cause some slight yellowing. These symptoms soon disappear.

In May 1989 a range of herbicides were applied to a mature stand of Puna chicory (Table 1). Bentazone (Basagran) and bromoxynil-ioxynil (Combine) had no or very little injurious effect on chicory; 2,4-DB was moderately harmful to chicory growth, but chicory recovered to produce a good seed yield; dicamba, picloram + 2,4-D (Tordon 50-D), glufosinate-ammonium (Buster) and chlorimuron (Classic) severely checked chicory growth, but the crop recovered in late spring to produce seed yields similar to that of the control. 2,4-D, clopyralid (Versatill) and glyphosate (Roundup) were very harmful, and despite chicory regrowing again in late spring, these chemicals are not recommended for weed control on chicory seed crops. Thistles (Cirsium and Carduus spp.) represent the most difficult to control weeds.

Table 1 Effect of a range of herbicides applied in May 1989 to mature Puna chicory.

\begin{tabular}{|c|c|c|c|c|}
\hline \multirow[b]{2}{*}{ Herbicide } & \multirow{2}{*}{$\begin{array}{c}\text { Rate } \\
\text { (kg ai/ha) }\end{array}$} & $\begin{array}{r}\text { Chicory } \\
\text { (visual } \\
\end{array}$ & $\begin{array}{l}0 \% \text { injury } \\
\text { estimate) }\end{array}$ & \multirow{2}{*}{$\begin{array}{c}\text { Seed yield } \\
\text { (kg/ha) } \\
14 \% \text { moisture } \\
\text { (Feb 1990) }\end{array}$} \\
\hline & & Jun 1989 & Sept 1989 & \\
\hline No herbicide & 0 & 0 & 0 & 552 \\
\hline Glyphosate & 2.16 & 73 & 100 & 229 \\
\hline $2,4-\mathrm{DB}$ & 2.4 & 3 & 47 & 554 \\
\hline $2,4-\mathrm{D}$ & 2.16 & 53 & 100 & 255 \\
\hline Clopyralid & 0.2 & 68 & 100 & 257 \\
\hline Chlorimuron & 0.03 & 37 & 77 & 618 \\
\hline Bromoxynil & & & & \\
\hline + ioxynil & 0.2 & 10 & 0 & 606 \\
\hline $\begin{array}{l}\text { Glufosinate- } \\
\text { ammonium }\end{array}$ & 1.2 & 90 & 63 & 512 \\
\hline Bentazone & 1.44 & 8 & 0 & 504 \\
\hline Dicamba & 0.4 & 53 & 97 & 472 \\
\hline $\begin{array}{l}\text { Picloram } \\
+2,4-\mathrm{D}\end{array}$ & $0.1+0.4$ & 37 & 80 & 538 \\
\hline LSD $5 \%$ & & 12 & 16 & 127 \\
\hline
\end{tabular}

\section{Pests and diseases}

In some seasons, aphids (Acyrthosiphon spp.) and tomato fruit worms (Heliothis armigera) have infested chicory seed crops during flowering. These pests have been controlled by a single application of dichlorvos (Dichlorvos 100 E, Nuvan 1000 EC). The synthetic pyrethroid insecticides, such as cyhalothrin
(Karate) or fluvalinate (Mavrik Aquaflow) are effective against aphids, sucking insects and caterpillars.

Root diseases (Sclerotinia spp.) can invade seed crops, particularly if soil conditions are wet. To avoid root diseases, chicory should not be sown after legumes (beans, peas), root crops (carrots, turnips, swedes, onions), tubers (potatoes) and some leaf crops (lettuce, rape and cabbage). No practical control measures for 'root diseases are available, except to move to a new site.

\section{Grazing}

Chicory will provide excellent forage the first summer following a spring sowing. Grazing must be quick, and down to no more than $5 \mathrm{~cm}$ above ground level. Chicory's rapid growth during the summer enables it to grow above many broadleaf weeds, many of which can be suppressed by grazing. During the winter the chicory plants are almost dormant. The crop should not be grazed heavily at this time as pressure on or damage to the plant crowns can kill plants.

Table 2 Effect of time of final defoliation (closing date) on Puna chicory seed yield (Hare \& Rolston 1987).

\begin{tabular}{|c|c|c|}
\hline \multirow{2}{*}{$\begin{array}{l}\text { Final defoliation date } \\
\text { (1st week of) }\end{array}$} & \multicolumn{2}{|c|}{ Seed yield $(\mathrm{kg} / \mathrm{ha})$} \\
\hline & $1984 / 85$ & $1985 / 86$ \\
\hline $\begin{array}{l}\text { May } \\
\text { August } \\
\text { September } \\
\text { October } \\
\text { November } \\
\text { December }\end{array}$ & $\begin{array}{r}236 \\
252 \\
282 \\
237 \\
194 \\
3-1\end{array}$ & $\begin{array}{l}228 \\
153 \\
171 \\
158 \\
128 \\
102\end{array}$ \\
\hline LSD $5 \%$ & 61 & 50 \\
\hline
\end{tabular}

In the North Island, seed crops of Puna chicory have been grazed in the spring until the beginning of October without any decrease in seed yield (Hare \& Rolston 1987); but only if there is good spring growth; defoliating after October reduces seed yields (Table 2). In the South Island, observation has shown that any late winter or early spring grazing will reduce seed yields substantially.

\section{Fertiliser}

Puna chicory responded to $50-100 \mathrm{~kg}$ N/ha (Table 3) depending on site and stand age. It appears likely that in older seed crops at least $100 \mathrm{~kg} \mathrm{~N} / \mathrm{ha}$ should be applied but a rate above this will not significantly $(P<0.05)$ increase seed yields.

Puna chicory may require other fertiliser elements, but until further research is done, we cannot give a recommendation other than for nitrogen.

\section{Irrigation}

Although chicory has a tap-root (which means that it can explore a large soil volume), the large leaf area of the plant means that evapotranspiration losses are 
Table 3 Effect of nitrogen on Puna chicory seed yields, (a) Manawatu, (b) Canterbury.

(a)

\begin{tabular}{|c|c|c|}
\hline & $\begin{array}{rr}\text { Machine harvested } \\
14 \% \text { moisture }\end{array}$ & $\begin{array}{l}\text { seed yield } \\
(\mathrm{kg} / \mathrm{ha})\end{array}$ \\
\hline $\begin{array}{l}\text { Nitrogen } \\
(\mathrm{kg} \quad \mathrm{N} / \mathrm{ha})\end{array}$ & $\begin{array}{c}1988 / 89 \\
\text { (3rd year crop) }\end{array}$ & $\begin{array}{c}1989 / 90 \\
\text { (4th year crop) }\end{array}$ \\
\hline $\begin{array}{r}0 \\
50 \\
100 \\
150\end{array}$ & $\begin{array}{l}472 \\
575 \\
608 \\
676\end{array}$ & $\begin{array}{l}451 \\
518 \\
587 \\
617\end{array}$ \\
\hline LSD $5 \%$ & 112 & 75 \\
\hline
\end{tabular}

(b)

\begin{tabular}{lc}
\hline & \multicolumn{2}{c}{$\begin{array}{c}\text { Hand harvested seed yield } \\
14 \% \\
\text { moisture (kg/ha) }\end{array}$} \\
\cline { 2 - 2 } Nitrogen & 1988/89 \\
(kg N/ha) & (2nd year crop) \\
\hline 40 & 631 \\
60 & 1122 \\
80 & 1243 \\
100 & 1508 \\
120 & 977 \\
140 & 1001 \\
LSD 5\% & 600 \\
\hline
\end{tabular}

high in hot dry conditions. Severe wilting has caused leaf loss in some Canterbury crops, resulting in a low seed yield, The crop should be irrigated when necessary to prevent wilting.

\section{Harvesting}

Flowering, pollination and seed development

Flowering in Puna stärts iii earty December and continues over several weeks, peaking in late December-early January (Hare 1986). The pale blue ray flowers open in the early morning and are closed by mid-afternoon. Puna is cross-pollinated largely by honey bees, but as in other chicory cultivars some self-pollination may occur (McGregor 1976). Two to three bee hives per hectare should be placed in or beside the field to ensure a good seed set. After pollination the flowers turn white and wilt.

Seed physiological maturity occurred 20 days after pollination in the Manawatu (Hare 1986). If night temperatures are cool (less than $10^{\circ} \mathrm{C}$ ), this period may be extended up to 40 days (Ayra \& Saini 1984). South Island growers should expect a longer period between pollination and seed maturity than North Island growers. Seed colour turns from a light brown-fawn to a deep brown at maturity (Hare 1986). However, the seed lot at harvest has dark brown and light brown seeds, as mature and immature seeds are harvested. At seed maturity the seeds are held tightly in the inflorescence, but can be lost by strong winds, heavy rain or by birds knocking out the seed.
Time of harvest

The extended flowering of chicory means that plants bear ripe seed and blue flowers at the same time. In New Zealand seed is harvested approximately 60 days after the first flowers appear. Sequential seed harvesting in the Manawatu showed that harvesting 19-30 days after the peak flowering (which is equivalent to 49-60 days after the appearance of the first flower) did not affect seed yield, but that earlier harvesting of the seed, 16 days after peak flowering (46 days after first flowers appeared), reduced yields significantly (Hare 1986).

By harvest time, some stems will be turning brown and the field will appear reddish brown from a distance rather than blue-grey. Closer examination will reveal seed on the ground, empty inflorescences from fallen seed, mature seed held tightly in inflorescences, and some green buds and blue flowers. Approximately $70 \%$ of inflorescences should have mature seed by $\mathbf{2 5 - 2 8}$ days after peak flowering.

\section{M ethod of harvest}

Puna can be desiccated or mown before harvest according to the availability of aerial applicators, high spray booms, and drying facilities, plus suitability according to shelter belts and weather (spray drift must be avoided). Seed yields of desiccated chicory are equal to those of mown chicory $(600 \mathrm{~kg} / \mathrm{ha}$ in Manawatu trials in 1988/89; Hare, unpubl. data).

Desiccate with diquat $(0.8-1.0 \mathrm{~kg}$ ai/ha), plus a surfactant (wetting agent) with a high water volume (300-400 l/ha). After desiccation the crop must be left to dry for 5-7 days (depending upon weather conditions) before direct heading. The crop at. this stage will have brown, desiccated top stems but green leaves and green stems towards the ground; in fields with sparse plant populations the whole stems can be brown. Stems can be cut low (to reduce stubble) or high (to avoid weed contamination and wet stems). Seed moisture varies according to weather conditions. If above $14 \%$ the seed should be dried immediately with cool forced air, as chicory seed is susceptible to heat damage.

Alternatively, the seed crop can be mown $20-50 \mathrm{~cm}$ above ground level, and stems left to dry in the field for 10 days or longer. This curing process allows continued maturation and the seed to dry down from about $\mathbf{4 0 \%}$ seed moisture at mowing to less than $15 \%$ moisture at threshing. Cutting the crop high allows the stems to be held above the ground and air will circulate underneath, speeding drying. The large hollow stems must be very dry before they can pass through a combine. Moist stems will cause excessive blockages in the feed-intake of the combine harvester. Dessicated crops are much easier to harvest than mown crops, with hardly any blockages occurring. The combine harvester should be set with a fast drum speed, a clover riddle and a little draught. 
Seed yields

Yields have ranged from 200 to $500 \mathrm{~kg} / \mathrm{ha}$, with some growers harvesting over $700 \mathrm{~kg} / \mathrm{ha}$ (machine dressed).

Seed quality

Good quality Puna seed should have a 1000 -seed weight of over $1.5 \mathrm{~g}$ with a germination of over $80 \%$. Germination percentage appears to be related to seed weight (Hare 1986). Some chicory seed lots have had low germinations which may be a result of harvesting too early, resulting in immature seed in the sample and not dressing the seed hard enough.

\section{REFERENCES}

Ayra, P.S.; Saini, S.S. 1984. 'Kalpa Sel 1' chicory. Ideal flavouring agent for coffee. Indian Horticulture 18: 55-56.

George, R.A.T. 1985. Vegetable seed production. London: Longmans.

Hare, M.D. 1986. Development of 'Grasslands Puna' chicory (Cichorium intybus L.) seed and the determination of time of harvest for maximum seed yields. Journal of applied seed production 4: 30-33.

Hare, M.D.; Rolston, M.P. 1987. Effect of time of closing and paclobutrazol (PP333) on seed yield of

'Grasslands Puna' chicory (Cichorium intybus L.). $\mathrm{New}$ Zealand journal of experimental agriculture 15 : 405-410.

Hare, M.D.; Rolston, M.P.; Crush, J.R.; Fraser, T.L. 1987. Puna chicory - a perennial herb for New Zealand pastures. Proceedings of the Agronomy Society of $\mathrm{New}$ Zealand 17: 45-49.

McGregor, S.E. 1976. Insect pollination of cultivated crop plants. Agriculture Handbook No. 496. Washington: Agricultural Research Service, United States Department of Agriculture. 